\section{Discussion}

The relationship between PRV and CLL when coexisting is not understood. Heinle et al. (1966) in describing three cases of PRV associated with CLL lymphoma and multiple myeloma, respectively, referred to the possibility of a unified histogenesis involving these disorders while Bethard et al. (1953) suggested that these two disorders are probably unrelated. Vianna and Essman (1971) noted a suppression of CLL by PRV in one patient in whom the two diseases co-existed. The present case does not show this phenomenon. Certainly the co-existence of two uncommon diseases would be exceedingly rare by chance alone and points to an association. If this is so, then a more likely explanation than unified histogenesis would be that of impaired $\mathrm{T}$ cell immunity in CLL which might predispose to the emergence of a second neoplastic clone. Hansen (1973) has reviewed the evidence for predisposition in CLL for a second neoplasia, and quotes eighteen series of CLL each showing a high incidence of solid tumours. While this is suggestive that predisposition occurs such series are highly selective and hence conclusions based on them are uncertain. Benign CLL which may be entirely asymptomatic may be more frequent than generally realized. Until this incidence is accurately known, the degree of predisposition of CLL for a second neoplasia must remain in doubt.

\section{Acknowledgment}

Gratitude is expressed to Mr M. Palmer, Statistical Department, Christie Hospital, for reviewing patient records and to Dr I. Todd, Christie, for permission to report a patient under his care.

\section{References}

Bethard, W.F., Block, M.H. \& Robson, M. (1953) Coexistent chronic lymphatic leukaemia with polycythemia vera: morphological and clinical studies with particular reference to unusual iron metabolism. Blood, 8, 973.

De BaKer, J. \& LAWREnCE, J.H. (1951) L'association de la leucémie à la polycythémie vraie. Presse Médicale, 59, 461.

HANSEN, M.M. (1973) Chronic lymphocytic leukaemia. Scandinavian Journal of Haematology (Suppl. 18).

Heinle, E.W., JR, Sarast, H.D., Garcia, D., Kennev, J.J. \& Westerman, M.P. (1966) Polycythemia vera associated with lymphomatous diseases and myeloma. Archives of Internal Medicine, 118, 351.

VianNa, N.J. \& EsSman, L.J. (1971) Suppression of chronic lymphocytic leukemia by polycythemia vera. Cancer, New York, Philadelphia, etc., 27, 1337.

\title{
Symptomatic hyponatraemia associated with tolbutamide therapy
}

\author{
B. A. Darlow \\ M.A., M.B., M.R.C.P. \\ Whittington Hospital, London N19
}

\begin{abstract}
Summary
A case of hyponatraemic coma occurring in a patient with diabetes mellitus treated with tolbutamide is described. Although chlorpropamide is known to cause water retention in some circumstances, this is a less well recognized complication of tolbutamide therapy.

\section{Introduction}

The antidiuretic action of chlorpropamide in diabetes insipidus is well described and it is probable that chlorpropamide acts by potentiating the renal response to small amounts of endogenous vasopressin (Miller and Moses, 1970). Patients with diabetes insipidus treated with chlorpropamide may develop water retention with symptomatic hyponatraemia (Webster and Bain, 1970). Patients with
\end{abstract}

diabetes mellitus treated with chlorpropamide may develop a similar complication, though only if fluid balance is already compromised by, for example, the co-existence of incipient or overt heart failure (Weissman, Shenkman and Gregerman, 1971). Not all sulphonylureas have a similar effect on water excretion and glibenclamide has been found to have a diuretic effect (Moses, Howanitz and Miller, 1973). The effects of tolbutamide are less clear. A case is now reported of symptomatic hyponatraemia associated with tolbutamide therapy in a patient with diabetes mellitus.

\section{Case report}

A 53-year-old lorry driver was admitted to hospital having been found unconscious at home. He had been a diabetic since a drainage operation for 
a pancreatic pseudocyst 4 years before and had been treated with diet and tolbutamide. The dose of tolbutamide had been $1 \mathrm{~g}$ t.d.s. for the last 27 months. He had occasional bouts of nausea and vomiting which were thought to be due to alcoholic gastritis. In retrospect it was discovered that for 3-4 days before the present admission he had been vomiting and drinking 'a large amount' of water (at least 5 pints daily). On examination he was irritable, with a fluctuating level of consciousness, had no abnormal pigmentation and normal secondary sexual characteristics. There was no oedema, and skin turgor was normal. The pulse was $120 / \mathrm{min}$, sinus rhythm, blood pressure was $190 / 90 \mathrm{mmHg}$, and his chest was clear. There were no localizing signs in the central nervous system and no neck stiffness; the fundi were normal; slight hyper-reflexia was present in the upper limbs.

\section{Investigations}

Serum sodium $115 \mathrm{mmol} / \mathrm{l}$; serum potassium 3.6 $\mathrm{mmol} / \mathrm{l}$; bicarbonate $17 \mathrm{mmol} / \mathrm{l}$; urea $5.3 \mathrm{mmol} / \mathrm{l}$; blood glucose $15.3 \mathrm{mmol} / \mathrm{l}$; plasma osmolality 242 $\mathrm{mmol} / \mathrm{kg} ; \mathrm{Hb} 15.2 \mathrm{~g} / \mathrm{dl}$; total white cell count $14,000 / \mu 1$. Chest X-ray: old tuberculosis; skull $\mathrm{X}$-ray: normal; ECG : within normal limits. Lumbar puncture: normal pressure, no cells, no bacterial growth. He was treated with i.v. $0.9 \% \mathrm{NaCl}$ (3 1 in $9 \mathrm{hr}$ ) and made a good recovery. Following recovery further investigations were as follows: after a fluid load of 1.51 in $3 \mathrm{hr}$ urine osmolality was $123 \mathrm{mmol} / \mathrm{kg}$; after an overnight fast urine osmolality was $598 \mathrm{mmol} / \mathrm{kg}$ and plasma osmolality was $287 \mathrm{mmol} / \mathrm{kg}$. His diabetes was treated with diet and insulin.

\section{Discussion}

The collapse of this patient and the impaired conscious level were undoubtedly related to his profound hyponatraemia. Following an intravenous infusion of normal saline he made a rapid recovery and was thereafter found to be able to concentrate urine after an overnight fast and to produce dilute urine after a water load. Furthermore, after his recovery his plasma sodium remained at normal levels. These features exclude most causes of hyponatraemia, including the syndrome of inappropriate $\mathrm{ADH}$ secretion due to malignant or non-malignant causes. There was no evidence of renal failure, congestive cardiac failure or cirrhosis. Psychogenic polydipsia can be discounted. Accumulation of a solute such as glucose in the extracellular fluid can create an osmotic gradient resulting in the movement of water out of cells into the extracellular fluid, but the blood glucose level of $15.3 \mathrm{mmol} / \mathrm{l}$ is insufficient to account for the actual degree of dilution present. Pseudohyponatraemia is accompanied by a normal plasma osmolality.
Repeated vomiting can, of course, result in depletion of sodium in excess of water and the resultant hyponatraemia may be accentuated by replacement with water alone. However, long before symptoms of hyponatraemia occur the low plasma osmolality causes a decrease in vasopressin secretion, resulting in increased urinary water loss and an increase in aldosterone secretion with retention of sodium and restoration of the plasma volume. In the present case it is postulated that these normal homeostatic events were altered by the presence of high levels of tolbutamide which enhanced the effect of, albeit low levels of, vasopressin and caused water retention and dilutional hyponatraemia.

Both chlorpropamide and tolbutamide have been shown to cause an antidiuresis in patients with primary diabetes insipidus (Fichman and Brooker, 1972), but whereas severe hyponatraemia is a well recognized complication of chlorpropamide therapy (Weissman et al., 1971; Editorial, 1971) there have been few reported cases in association with tolbutamide. Hagen and Frawley (1970) exhaustively investigated a case of hyponatraemia associated with high doses of tolbutamide ( $3 \mathrm{~g}$ daily), but their patient had idiopathic cerebral atrophy and recovery of conscious level and electrolyte balance took several days. The present case indicates that induced hyponatraemia can occur as a complication of tolbutamide therapy, at least when fluid balance is already compromised.

\section{Acknowledgment}

I am grateful to Dr E. R. Beck for permission to report this case.

\section{References}

EDITORIAL (1971) Chlorpropamide and hyponatraemia. Lancet, i, 368.

Fichman, M.P. \& Brooker, G. (1972) Deficient renal cyclic adenosine $3^{\prime}-5^{\prime}$ monophosphate production in nephrogenic diabetes insipidus. Journal of Clinical Endocrinology and Metabolism, 35, 35.

Hagen, G.A. \& Frawley, T.F. (1970) Hyponatraemia due to sulphonylurea compounds. Journal of Clinical Endocrinology and Metabolism, 31, 570.

Miller, M. \& Moses, A.M. (1970) Mechanism of chlorpropamide action in diabetes insipidus. Journal of Clinical Endocrinology and Metabolism, 30, 488.

Moses, A.M., Howanitz, J. \& Miller, M. (1973) Diuretic action of three sulphonylurea drugs. Annals of Internal Medicine, 78, 541.

Webster, B. \& Bain, J. (1970) Antidiuretic effect and complication of chlorpropamide therapy in diabetes insipidus. Journal of Clinical Endocrinology and Metabolism, 30, 215.

Weissman, P.N., Shenkman, L. \& Gregerman, R. (1971) Chlorpropamide hyponatraemia: drug-induced inappropriate antidiuretic hormone activity. New England Journal of Medicine, 284, 65. 